Pobrane z czasopisma Annales I - Philosophy and Sociology http://philosophia.annales.umcs.pl Data: 26/04/2023 09:41:02

10.1515/sectio-2015-0024

A N N A L E S

UNIVERSITATIS MARIAE C URIE-SKŁODOWSKA

L U B L I N - P O L O N I A

VOL. XL, 1

SECTIO I

2015

Uniwersytet Marii Curie-Skłodowskiej w Lublinie

MATEUSZ BUCZEK

\title{
Wolnorynkowa alternatywa \\ dla „demokratycznego państwa prawa”
}

\begin{abstract}
J.M. Oliver, The New Libertarianism: Anarcho-Capitalism: From Objectivist Basic Premises to Political Concepts, Leipzig 2013, ss. 188.
\end{abstract}

J.M. Oliver był badaczem obiektywizmu (głównie w wersji głoszonej przez Ayn Rand) od 1965 roku. W latach 60. i 70. był bardzo aktywnym członkiem małego, dopiero wyłaniającego się ruchu libertariańskiego. W tym okresie rozmaite prądy libertarianizmu nabierały tempa i umacniały swoje idee. W 1971 roku autor został założycielem i redaktorem „The New Banner”, funkcjonującego w kręgach narodowych obiektywistycznego czasopisma, które w pełni przyjmując filozoficzne przesłanki Ayn Rand, odrzuciło jednocześnie jej pomysły ograniczonego rządu, wnioskując w zamian, że anarchokapitalizm jest logicznym/praktycznym stanowiskiem filozofii obiektywistycznej. W 1975 roku Oliver zrezygnował z możliwej kariery akademickiej w zakresie filozofii politycznej i stał się (wraz z E.F. Huttonem) specjalistą przewidywania rynku złota. Kontynuował tę pracę do 1992 roku, aż zdecydował się zostać analitykiem rynku. Korzystając z wypracowanej przez siebie metodologii technicznej analizy, zapewniał koordynację i wykonywał badania analityczne dla spółek, funduszy hedgingowych i instytucji finansowych przez ponad 20 lat. Obecnie mieszka w St. Louis w stanie Missouri.

Recenzowana publikacja powstała na podstawie pracy dyplomowej o tym samym tytule, napisanej przez Olivera w 1972 roku na University of South Carolina (Department of Government and International Studies). Książka nie była publikowana nigdzie wcześniej, aż do roku 2013, jednak autor zastrzega, że nie aktualizował jej treści według bieżących wydarzeń czy trendów. Twierdzi jednocześnie, że taki zabieg byłby bezcelowy, jako że praca nie jest „,produktem z datą” 
Pobrane z czasopisma Annales I - Philosophy and Sociology http://philosophia.annales.umcs.pl Data: 26/04/2023 09:41:02

(s. 7), lecz traktuje o rdzennych koncepcjach, które posiadają ponadczasową wartość i zastosowanie. Krok taki jest równie odważny, co słuszny. Odważny, ponieważ otrzymujemy informację, że autor, po czterdziestu latach od napisania pracy, nadal jest pewny swych tez. Słuszny zaś dlatego, że każda osoba zaznajomiona z tematyką libertarianizmu uzna to za przesłankę zgodności z tym poglądem, albowiem fundamenty libertarianizmu są stałe, niezależne historycznie i kontekstowo. Książka ta w zamierzeniu autora nie ma być „wezwaniem do broni” (ponieważ tytuł ze słowem „anarchia” może budzić takie skojarzenia), tylko próbą połączenia wyłaniającego się ruchu libertariańskiego z najistotniejszymi założeniami obiektywizmu Ayn Rand (mimo konfliktu na linii: Rand - anarchokapitalizm Rothbarda - nowocześni libertarianie). Autor chce dotrzeć do jednolitego poglądu na temat rzeczywistości i człowieka, a następnie dokonać połączenia tego poglądu z pasującą do niego teorią polityczno-ekonomiczną.

Dzieło zostało podzielone na dziewięć różnych objętościowo części. O ile w przypadku takich części książki, jak przedmowa, wprowadzenie czy notka biograficzna o autorze można wybaczyć ich nieregularność (pomiędzy 1 a 5 stron), o tyle zmieszczenie wniosków końcowych na dwóch stronach powoduje co najmniej zdziwienie. Rozdziały zawierające główną treść również nie są proporcjonalne objętościowo - rozdział Objectivism zajmuje 26 stron, rozdział The State to już 62 strony, natomiast rozdział Capitalism/Voluntarism rozciąga się aż na 72 strony. Ciekawostką jest posłowie - Afterword: Personal Encounters (napisane, podobnie jak wprowadzenie, w 2013 roku), obejmujące niepełne pięć stron. Autor opisuje w nim wrażenia z osobistych spotkań z Ayn Rand i Murray’em Rothbardem.

We wprowadzeniu Oliver słusznie zauważa, że na współczesnej scenie politycznej powstało mnóstwo wąsko zorientowanych na pojedyncze problemy partii, których działania nakładają się na siebie. Równie słusznie wskazuje na potrzebę istnienia przekrojowego ruchu ideologicznego, który skoncentruje jak najwięcej uwagi ze strony badaczy idei politycznych i filozoficznych.

Autor, chcąc pozostać w zgodzie z metodologią, w celu umożliwienia zrozumienia swojej teorii odsyła nas do jej filozoficznego fundamentu, którym według niego jest filozofia obiektywizmu (mimo iż, jak twierdzi, uczynienie z filozofii obiektywizmu takiego fundamentu nie było zamiarem jego twórczyni - Ayn Rand). Pozwala to czytelnikowi zrozumieć, dlaczego pierwszym, zasadniczym rozdziałem został ten dotyczący właśnie obiektywizmu. Drugi z rozdziałów (The State) ma być wieloaspektową krytyką rządu, podważającą między innymi pospolite założenia dotyczące początków, istoty, metod i skutków działania rządu. Ostatni rozdział (Capitalism/Voluntarism) to propozycja alternatywy dla kontrolowanego przez państwo społeczeństwa, którą jest społeczeństwo wolnorynkowe.

W pierwszym rozdziale (Objectivism) odnajdujemy na początku rys historyczny powstania obiektywizmu oraz przybliżenie sylwetki jego twórczyni, Ayn Rand. Zabieg ten zasługuje na pochwałę, umożliwia bowiem zrozumienie tema- 
Pobrane z czasopisma Annales I - Philosophy and Sociology http://philosophia.annales.umcs.pl Data: 26/04/2023 09:41:02

Wolnorynkowa alternatywa dla „demokratycznego państwa prawa”

tyki pracy nawet tym osobom, które wcześniej nie miały z nią kontaktu. W następujących po tym krótkim wstępie podrozdziałach Oliver prezentuje i omawia kolejno: metafizykę (Metaphysics), epistemologię (Epistemology), zagadnienie woli (Volition) oraz etykę (Ethics) - ostatni podrozdział zajmuje najwięcej miejsca. Bez niepotrzebnego rozwlekania problemu, używając zrozumiałego i prostego języka, Oliver w kolejnych krokach referuje wyżej wymienione zagadnienia. Wszystkie tezy wspiera logiczną argumentacją, zaś bardziej skomplikowane problemy tłumaczy na przykładach. Autor na poparcie swych słów przytacza cytaty nie tylko współczesnych twórców obiektywizmu, ale sięga również wstecz, chcąc wskazać np. na wielowiekowy charakter problemu ludzkiej woli, jednocześnie poddając krytyce jeden z fragmentów Etyki Spinozy.

Rozdział drugi (The State) jest krytyką państwa. Autor na samym początku wskazuje na fakt, iż żyjemy w czasach wszechwładzy rządu. Zauważa, że jego przywileje sięgają dużo dalej niż władza siedemnasto- i osiemnastowiecznych monarchów, a ingerencja w codzienność ludzi jest na poziomie wyższym niż w czasach rządów Hitlera czy Stalina. Argumentuje, że zwolennicy rządu opierają swoje argumenty na relatywistycznych i niesprawdzonych przesłankach, które już dawno zostały wykluczone z poważnej, intelektualnej dyskusji. Rozdział ten został podzielony na następujące części: Society, Rights, Origin of the State: Contract or Coercion?, „Limited” Government, Objective Law v. Government Law, Violent Intervention, Stagnation. Tak jak w poprzednim, również i w tym rozdziale argumentacja nie zawodzi. Autor wspiera się między innymi znanymi libertarianom cytatami z pism Rothbarda, Rand, a także twórcy klasycznego liberalizmu - Johna Locke'a. Powoływanie się na tego ostatniego pokazuje, że - po pierwsze - autor nie odcina się od tradycji i nie pozostaje jedynie w kręgu nowoczesnych wolnościowców, a po drugie - udowadnia tezę ze wstępu o ponadczasowości prezentowanych poglądów. Oprócz odwoływania się do teorii Oliver przytacza również fakty, np. wspominając historię Lysandera Spoonera (którego nazywa się ojcem anarchokapitalizmu) i jego walki z systemem i rządem.

Trzeci, ostatni z rozdziałów (Capitalism/Voluntarism) rozpoczyna się przedstawieniem niekompatybilności współczesnego (i jakiegokolwiek opartego na państwie) społeczeństwa ze społeczeństwem libertariańskim. Biorąc za kryterium neutralne i powszechne libertariańskie aksjomaty, Oliver zestawia je z tym, co możemy zastać obecnie i konkluduje, że dla istnienia takiego wolnościowego społeczeństwa niezbędne jest odwołanie się do rozumu i odejście od przymusu, a filozoficzna zmiana w umysłach ludzi jest koniecznością. Kolejne podrozdziały noszą nazwy: The False History of Capitalism, Monopoly, Economic Power, Government and Society, Anarcho-Capitalist Society. Następujący po nich podrozdział Scenario został podzielony na jeszcze mniejsze części składowe, budujące całą historię mającą przedstawić hipotetyczne funkcjonowanie wolnego rynku. „Scenariusz” traktuje o przebiegu procesu prawnego w przypadku przestępstwa. 
Pobrane z czasopisma Annales I - Philosophy and Sociology http://philosophia.annales.umcs.pl Data: 26/04/2023 09:41:02

Jego części to: Crime, Apprehension, Arbitration, Restitution, Tendency Toward Non-Violence oraz Defense Agencies. Następny podrozdział dotyczy w całości sądownictwa (Arbitration) w realiach wolnego rynku. Po nim zostaje rozwinięta tematyka zadośćuczynienia (Restitution Company), proponowana w formie przypominającej ubezpieczenie OC. Ostatnie dwa podrozdziały to zadośćuczynienie (Rehabilitation) oraz obrona przed zorganizowaną i wielkoskalową agresją (Defense Against Organized and Massive Aggresion). Argumentacja, podobnie jak w poprzednich rozdziałach, jest przeprowadzana rzetelnie, logicznie oraz z przywołaniem odpowiedniej literatury. Scenariusze i przewidywania są natomiast bardzo interesującą ciekawostką, która powinna zwrócić uwagę nie tylko tych, którzy nie potrafią wyobrazić sobie życia bez państwa, ale także tych, którzy do wolnego rynku nie są do końca przekonani.

We wnioskach końcowych (Conclusion) Oliver postuluje libertarianizm jako konkurencję dla utrwalonych powszechnie w ludzkiej świadomości programów politycznych. Według niego mają one w najbliższym czasie tracić na znaczeniu zarówno w dyskusji akademickiej, jak i w społecznej świadomości. Wybór nie musi być już ograniczony pomiędzy umową społeczną a „wojną każdego z każdym”. W ostatnim wniosku stwierdza, że anarchokapitalizm jest niczym innym, jak politycznym aspektem szerszej, obiektywistycznej rewolucji filozoficznej (s. 172).

Podsumowując, książka jest napisana poprawnie, język w niej użyty jest klarowny i nie razi czytelnika natłokiem specjalistycznego, naukowego słownictwa, które ograniczałoby grono odbiorców do społeczności akademickiej, mimo iż jest to praca stricte naukowa (sic!). Z dzieła J.M. Olivera z pewnością zrobią użytek osoby, które chciałyby zapoznać się z tematyką wolnościową. Publikacja okaże się przydatna również dla osób obeznanych już w tej tematyce, stanowiąc źródło kolejnych argumentów w dyskusjach, a także jako ciekawa synteza poglądów Rand i Rothbarda. Pracy tej nie należy przy tym traktować jako encyklopedii światopoglądów wolnościowych, gdyż jej przedmiot dotyczy jedynie kilku z nich.

Uczciwie należy przyznać, że autor wywiązał się z obietnic danych we wstępie. Mimo dużej rozbieżności w objętości rozdziałów, należy polecić tę książkę do lektury. 